\title{
EVALUATION AND CHARACTERIZATION OF THE SEED OILS OF TRICHOSANTHES CUCUMERINA (SNAKE GOURD) AND RICINODENDRON HEUDELOTII/HONEY PLUM)
}

V. S. EKAM

(Received 3 Jume 2002: Revision areepted 28 ()ober.002).

\begin{abstract}
The estimation of the chemical composition and physical properties of the seed oils of Trichosanthes cucumerina and Ricinodendron heudelotii using standard methods of analysis showed that the seed of $T$. cucumerina and $R$. heudelotii have high oil content (46.3 $\pm 4 \%$ and $42.5 \pm 5 \%$ respectively). Assessment of the physical constants revealed that Ricinodendron heudelotii had a low heat of combustion $(12: 9 \pm$ $3 \mathrm{kcal} / \mathrm{g})$ when compared to that of Trichosanthes cucumerina $(32.8 \pm 4 \mathrm{kcal} / \mathrm{g})$. The refractive indices at $40^{\circ} \mathrm{C}$, boiling point, smoke point and flash points were high in the two oils. Their relative densities were high and their melting points were low. From the chemical parameters, the high ester value and saponification values of $T$. cucumerina and $R$. heudelotii qualifies them to be used in industries for soap making, while the high lodine value for $R$. heudelotii (158.8 $\pm 8 \mathrm{gl} / 100 \mathrm{~g}$ oil) qualifies it as a drying oil and suggest possible usefulness in the paint industry. Their percentage free fatty acid and acid values were low suggisting increased stability and usefulness in nutritional and industrial applications.
\end{abstract}

Key Words: seed oll, chemical composition, Trichosanthes cucumerina, Ricinodendron heudelotii.

\section{INTRODUCTION}

Thichosanthes cucumerina (snake gourd) is believed to have originated in South East Asia (Herklots, 1972). It is a member of the family Cucurbitaceae, which also includes water melon and buffalo gourd. There are over forly species of Tiichosanthes with only a few including. T.cucumerina, having edible fruits. The plant is a quick growing, rather large annual, climising by means of twining and by attachment to its support by means of tendrils, which have three to five branches (Rice et al., 1993). The seeds are yellow brown to earth brown with a rough body surface, and are sown at the beginning of the rains at the feet of a solid support, which will allow the fruits to hang freely. The fruits which may be up to $120 \mathrm{~cm}$ in length and 5 to $10 \mathrm{~cm}$ in width mature in about three months; are largely green in color interspaced with a chalky white wax surface when young; and orange or dark red when ripe. The seeds are embedded in a red pulp (Herklots, 1972)

Richodendron heudelotii (honey olumi) is a member of the family Euphorbiacear, a species of the deciduous forest particularly characteristic of secondary growth. It is identifiable in piactice by its compound digitate leaves with three to five leaflets, slightly fleshy 2 to 3 lobed vellow fruits. and its scaly brownish bark with granular redish slash. It is a large tree with carducous leaves reaching $45 \mathrm{~m}$ in height and $150 \mathrm{~cm}$ in diameter. The tree has greenish unisexual flowers with terminal panicles and flowers between March and May. The plant is a tree resembling, Ricinus, the castor oil plant (Keay, 1989). Only one species grows in Nigeria, and this is Ricinodendron heudelofii (Heckel subsp.) Africanum. The plant is known by different names in the different parts of Nigeria, among which include Okhuen (Hausa), Oke (Urhobo), Okengbo (ljaw) and Okwe (Igbo) The species extend from Southern Nigeria eastwards to Sudan, Tanzania, Angola and Mozambique. (Keay, 1989)

Due to the ever increasing utilization and demand for vegetable oils for local consumption and the production of finished goods both in food and feed industries as well as in other industrial processes like the production of paints, soaps, lubricants and pharmaceuticals for local use and for export; coupled with a decline in the production of the commonly used sources of oil in Nigeria, the price of processed oils as well as that of their finished products has continued to rise. This apparent inability to produce enough oil has also resulted in the importation of oils, contributing to inflation, wasteful use of foreign exchange as well as underutilization of the abundant human and natural resources available in Nigeria.

Given the increasing cost of oils for human goods and animal feeds, and the increasing knowledge of the role of dietary fats, it becomes desiraile to improve the range and availability of edible oils with desirable characteristics (Gunstone and Harwod, 1986), to complement the aiready 
existing sources without causing any damage to the environment. This can be done by exploiting the hitherto untapped sources of the oil seeds, which abound locally in tropical forests.

\section{MATERIALS AND METHODS}

The seeds of Trichosanthes cucumerina were obtained from a garden in Calabar, while those of Ricinodendron heudelotii were obtained in the South-West province of Cameroon. The hard outer covering of these seeds were removed and the succulent inner portions were blended and reduced to a fine meal after predrying in an oven (Galienkamp DV 330 ) at $65^{\circ} \mathrm{C}$ to reduce the moisture content; and used for the extraction and analysis. Lipid extraction and estimation was done by soxhlet extraction using the method of $A$ O A C (1984). The acid value was determined by the method of Devine and Williams (1961), which involved titration of $0.1 \mathrm{M}$ sodium hydroxide with $2 \mathrm{~g}$ of oil sample, dissolved in neutral alcohol using phenolphthalein indicator. The colline value was determined by the method of Strong and Kock (1974) which is based on the absorption of iodine vapour by the fatty acids exposed to it in a fume chamber. The saponification value was determined by titration of $2 \mathrm{~g}$ of oil sample in $20 \mathrm{ml}$ of $0.1 \mathrm{M}$ alcoholic potassium hydroxide with $0.5 \mathrm{M}$ hydrochloric acid using phenolphthalein indicator(AOAC,1984). The ester value was estimated by the method of Williams, (1950) as the difference between the saponification value and the acid value. The percentage free fatty acid value was estimated from the acid value by the method of Gunstone and Harwood (1986). The saponification equivalent was estimated from the saponification value by the method of Harwood and Hendrikse (1986). The heat of combustion was calculated by the method of Bailey,(1979) from the iodine value and the saponification value, while the refractive index was estimated at $40^{\circ} \mathrm{C}$ using the saponification value acid value and iodine value by the inethod of Bailey,(1979). The melting point and slip point were obtained by the method of Harwood and Hendrikse,(1986) using capillary tubes connected to a caliberated thermometer. The relative density was obtained as the ratio of the volume of the oils to that of an equal volume of water using the

Table 1: Physical properties and percentage lipid of Trichosanthes cucumerina_ and Ricinodendron heudelotii (mean \pm standard deviation)*

\begin{tabular}{|l|l|l|}
\hline Parameters & T. cucumerina & R. heudelotii \\
Lipid colour & $46.3 \pm 4$ & $42.5 \pm 5$ \\
Heat of Combustion $(\mathrm{kcal} / \mathrm{g})$ & $32.8 \pm 4$ & Golden Yellow \\
Refractive index $\left(40^{\circ} \mathrm{C}\right)$ & $1.4567 \pm 0.02$ & $12.9 \pm 3$ \\
Boiling Point $\left({ }^{\circ} \mathrm{C}\right)$ & $210 \pm 10$ & $1.4545 \pm 0.03$ \\
Smoke Point $\left({ }^{\circ} \mathrm{C}\right)$ & $260 \pm 20$ & $220 \pm 15$ \\
Flash Point $\left({ }^{\circ} \mathrm{C}\right)$ & $350 \pm 20$ & $270 \pm 18$ \\
Melting Point $\left({ }^{\circ} \mathrm{C}\right)$ & $3 \pm 1$ & $6 \pm 2$ \\
Slip Point $\left({ }^{\circ} \mathrm{C}\right)$ & $3 \pm 1$ & $5 \pm 2$ \\
Relative density $\left(25^{\circ} \mathrm{C}\right)$ & $0.859 \pm 0.004$ & $0.934 \pm 0.006$ \\
\hline
\end{tabular}

${ }^{*}$ mean of 3 determinations 
(4) Table 2:

Chemical Characteristics of the oil of T. cucumerina and R. heudelotii $(\text { mean } \pm \text { standard deviation })^{*}$

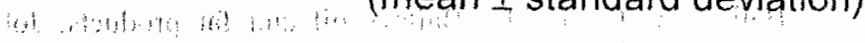

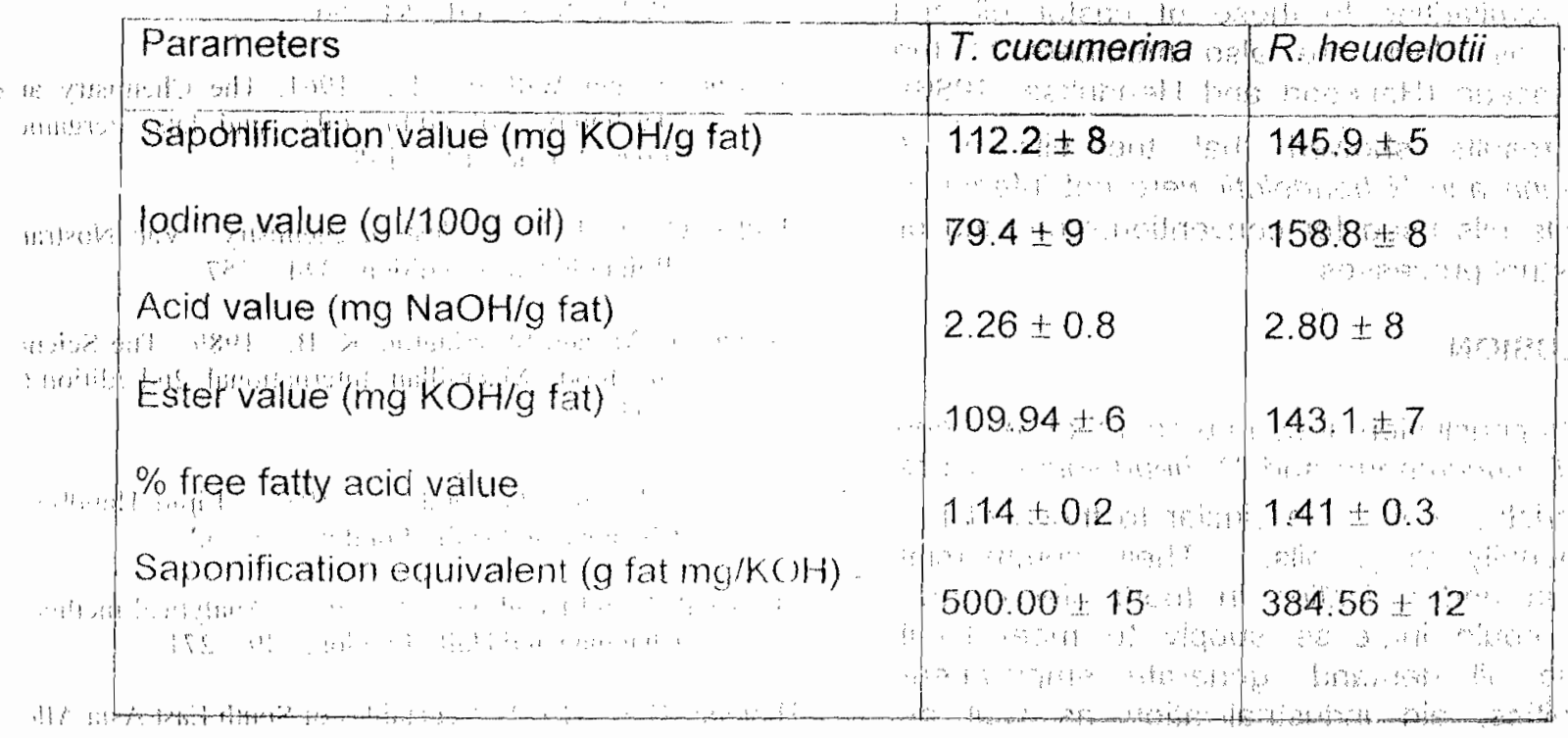

* mean of 3 determinations

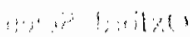

method of Harwood and Hendrikse (1986). The boifing point smoke point and flas: unt were determined by the method of manan and Sherrington, (1089)

\section{RESUL TSANO DISCUSSION}

The percentage yleld of oils as show in table 1 reveals that $T$ cycumerina $(46,3+4 \%$ and $R$ helidelotii $(42.5,5 \%)$ have high, oil yield. On account of their high oil content, the can therefore be classified as oil seeds. The two seed oils had different shades of yellow colour, with $R$. heudelottii having a golden yellow colour and $T$. cucumerina a brownish yellow colour.

The values of the other physical properties for $T$. cucumerina and $R$. heudelotii were: heat of cumbustion $(32.8 \pm 4 \mathrm{kcal} / \mathrm{g}$ and $12.9 \pm 3 \mathrm{kcal} / \mathrm{g}$ respectively), boiling point $\left(210 \pm 10^{\circ} \mathrm{C}\right.$ and 220 $15^{\circ} \mathrm{C}$ respectively), smoke point $\left({ }^{\circ} \mathrm{C}\right)(350 \pm 20$ and $360+12$ respectively), melting point $\left({ }^{\circ} \mathrm{C}\right)(3.0$ +1 and $6.0 \pm 2$ respectively), slip point $\left({ }^{\circ} \mathrm{C}\right)(3.0$ 1 and $5.0+2$ respectively), refractive index at $40^{\circ} \mathrm{C} \quad(1.4567 \pm 0.02$ and $1.4545 \pm 0.03$ respectively) and Relative density $\left(25^{\circ} \mathrm{C}\right)(0.859 \pm$ 0.004 and $0.934 \pm 0.006$ respectively). The values of the physical properties of both oils point to their high themostability and usefulness in high temperature operations and food processing (Gaman and Sherrington, 1989), similarly the high viscosity could also facilitate their use in the manufacture of lubricants while the low melting point of the oils suggests the presence of possibly low percentage of solids or impurities at these temperatures which could be useful for margarine production or other food processors who need to control the characteristics of their manufactured products by blending (Fuller, 1974).

Table 2 shows the chemical characteristics of the ofl extracted from the oilseeds. The high ester values for T. cucumerina (109.94+6 $\mathrm{mg} \mathrm{KOH/g}$ fat) and $R$ heudelotif (143.1 $7 . \mathrm{mg} \mathrm{KOH} / \mathrm{g} \mathrm{fat})$ and the high saponification value for $T$. cucumerina $(112.2$ t $8 . \mathrm{mg} \cdot \mathrm{KOH} / \mathrm{g}$ fat $)$ and $R$. heudelotii $(145 \pm 5 \mathrm{mg} \mathrm{KOH} / \mathrm{g}$ fat $)$ suggests the preponderance of glycerides of low molecular weight, which could make these oils useful in the manufacture of soaps, detergents and lather shave creams. The high iodine value of $R$. heudelotil (158.8 $\pm 8 \mathrm{gl} / 100 \mathrm{~g}$ oil) points to the presence of many unsaturated bonds which qualifies this oil as drying oil and so maybe usefut in the paint industry. The unsaturation of the fatty acids of these oils makes them nutritionally preferred especially by individuals prone to heart problems (Abalaka et al, 1988).

The two seed oils had a low percent free fatty acid values which suggests low lipolytic activities that could improve the stability of the oils since high free fatty acid implies degradation which could possibly cause rancidity to set in (Fuller, 1974) The analysis of the seed oil of $T$. cucumerima revealed similar characteristics to those of buffalo gourd oil which is also a member of the cucurbitaceae family (Gunstone and 


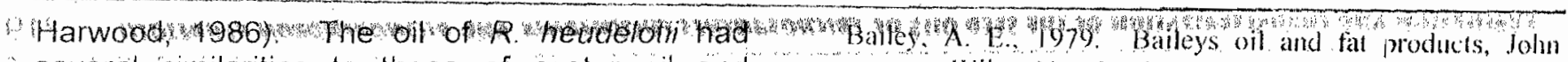
several similarities to those of castor oil and Wiley, New York. 84 90

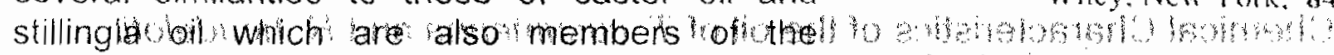

Euphobiaceae (Harwood and Hendrikse, 1986)

These results showed that the oils of $T$ cucumerina and R heudelotii werenot inferior to the edible oils used for conventional cooking or for industrial processesi?

a 3

\section{CONCLUSION}

In conclusion, it can be said that the seed oils of $t$. cucumerina and $f$. heudeiotii possess characteristics which are similar to those of the conventionally used oils. Their commercial production and utilization in foods, feeds and industry could increase supply to meet local vegetable oil demand, generate employment opportunities, aid industrialization as well as reduce Nigeria's dependence on imported oil thereby conserving our much needed foreign exchange.

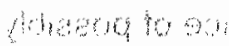

SLERTENOS

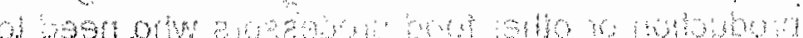

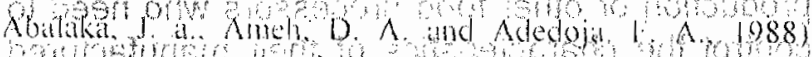

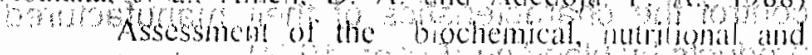
industrin qualities th ruber sed oft Noetan

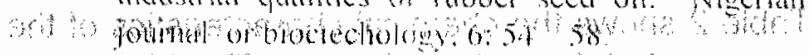

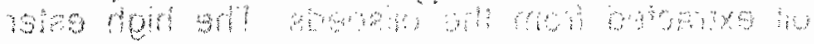

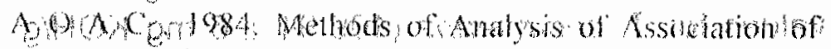

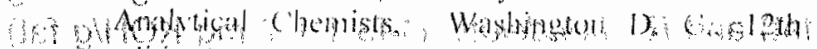

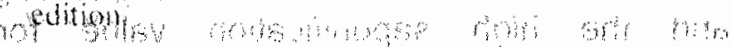

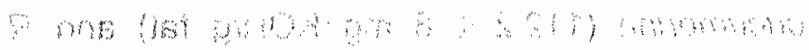

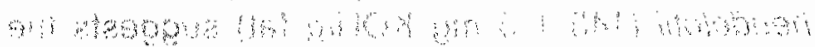

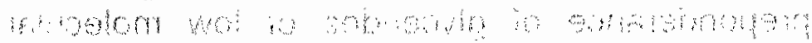

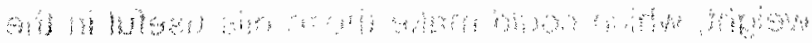

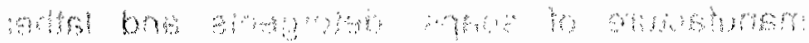

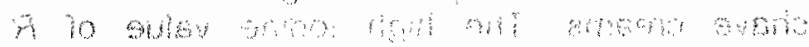

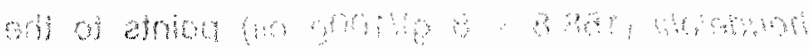

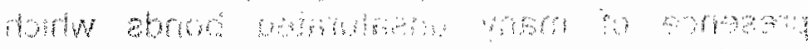

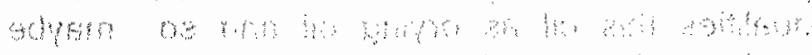

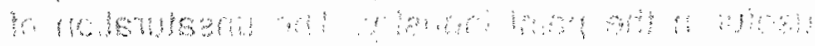

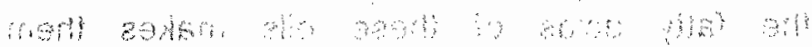

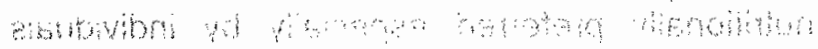

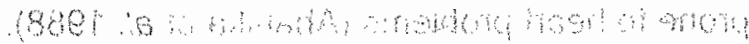

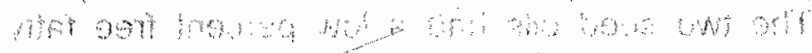

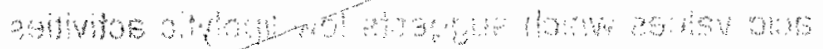

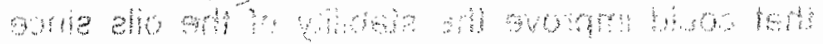

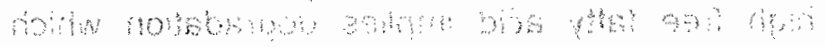

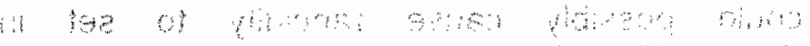

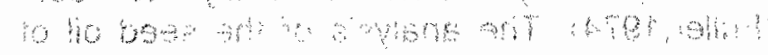

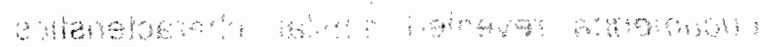

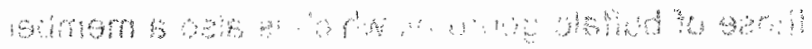

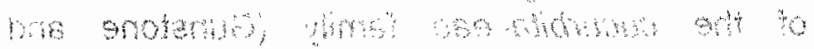

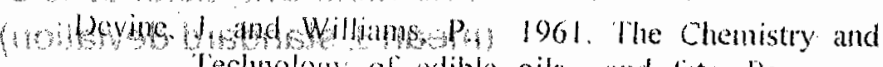
rechmology of edible oils and lints. Pergamon Press: lonklom 127-138

Fuller (. O. 1974. industria! chemistry. Vam Nostrand (1) Romoldgon 7 adtiono 344357

Gaman, P. M. amd slicrington, K., 3, 1989, las Science of food. Nhichillan Imenational, and edition 62 63

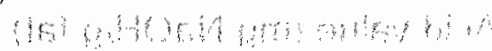

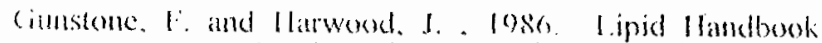

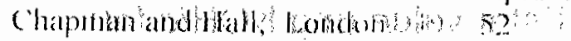

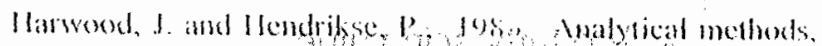
(hapman and hall, london, 249 271

(1) Hethots. OC. 1972 . Vegenbles of South East Asia Allen and Unwin, London. $346 \cdots 349$

Keay. R. J. 1989. Trees of Nigeria, Oxford Scionce Publication $152 \cdots 153$

Rice, R. Rice. L and Thindatl, H. 1993. Fruit and vegetable prodiction in Africa. Macmillan lrests, Hong Kong 159-196.219,220

Strong $F$ M. and Kock G H. 1974 Biochemistr labonatory manul W. M.C. Brown Publishers $2^{\text {ind }}$ edn. I) ubuque. Jowa, $336 \ldots 34 \%$

Willams, K. A. 1950) Oth tats and Talk Foods, J A Chuchill Letd, Lotiom. 76.110

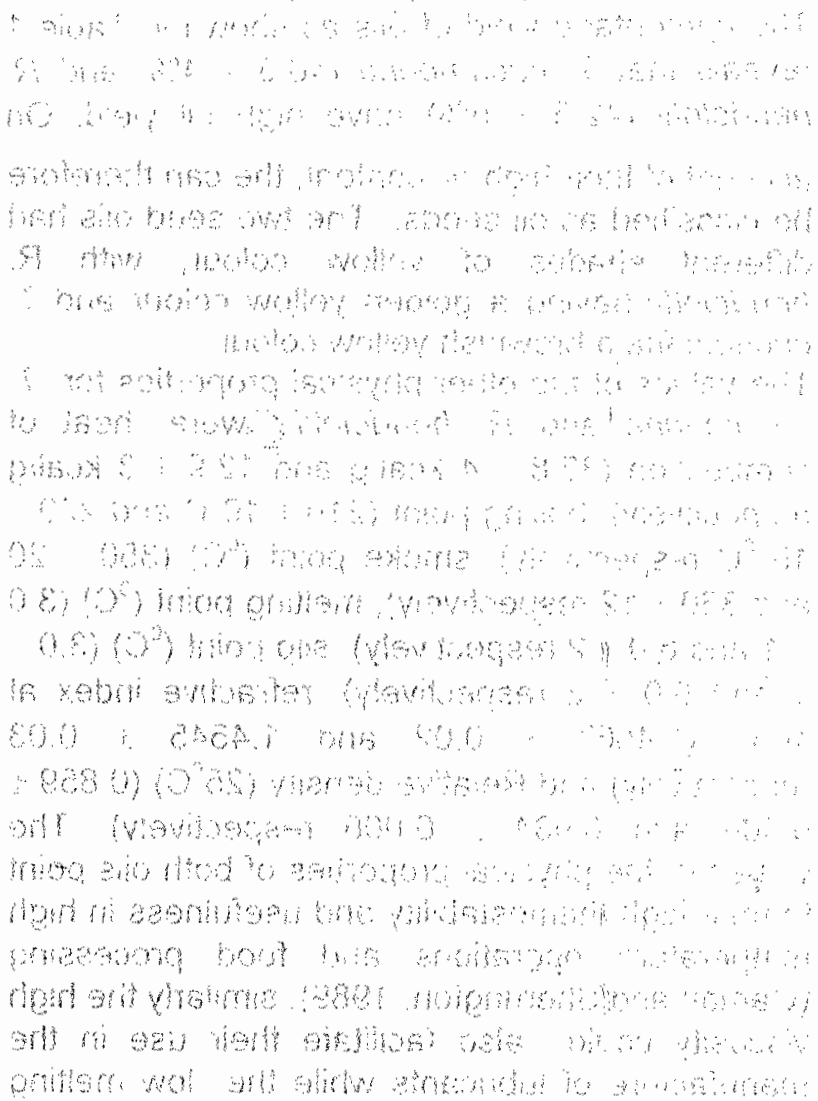

